Yoel, A. • M. Rachmadi

\title{
Evaluasi galur-galur mutan kedelai berdasarkan daya hasil dan ukuran biji di Jatinangor, Sumedang, Jawa Barat
}

Sari Kegiatan pemuliaan tanaman kedelai saat ini sebagian besar berfokus untuk mengidentifikasi genotipe-genotipe dengan hasil tinggi dan ukuran biji besar. Tujuan penelitian ini adalah untuk mengevaluasi galur-galur mutan kedelai berdasarkan daya hasil tinggi dan ukuran biji besar. Penelitian ini dilaksanakan dari September 2017 sampai Januari 2018 di Kebun percobaan Ciparanje, Fakultas Pertanian, Universitas Padjadjaran, Jatinangor, Jawa Barat. Rancangan percobaan yang digunakan adalah Rancangan Acak Kelompok (RAK) yang terdiri dari 19 galur mutan kedelai dan varietas Arjasari sebagai cek, dengan dua ulangan. Data dianalisis dengan analisis varians serta diuji beda rata-rata Dunnet masing-masing dengan selang kepercayaan 95\%. Hasil penelitian menunjukkan bahwa terdapat galur-galur mutan kedelai yang memiliki daya hasil dan ukuran biji yang lebih tinggi dari varietas Arjasari. Galur mutan kedelai 85.4 lebih tinggi dibandingkan Arjasari pada daya hasil, panjang biji, lebar biji, dan bobot 100 biji. Sedangkan galur mutan kedelai 23.1 lebih tinggi dibandingkan Arjasari pada daya hasil, panjang biji, dan lebar biji.

Kata kunci: Kedelai · Ukuran biji · Bobot 100 biji · Varietas · Arjasari

\section{Evaluation of soybean mutant lines based on yield and seed size in Jatinangor, Sumedang, West Java}

\begin{abstract}
Current soybean breeding focused largely on identifying genotypes with high-yield and large seed size. The objectives of this research was to evaluate of soybean mutant lines for yield and seed size. This research was conducted from September 2017 until January 2018 at Ciparanje Experimental Station, Faculty of Agriculture Universitas Padjadjaran, Jatinangor, West Java. The Randomized Block Design (RBD) was used in this experiment and nine teen soybeans mutant lines as treatment included Arjasari variety as check and replicated twice. The data were analyzed with using analysis of variance and mean comparison test of Dunnet each with confidence interval $95 \%$. The results showed that there were soybean mutant lines that have higher yield and bigger size than Arjasari. Soybean mutant line 85.4 was higher than Arjasari in yield, seed length, seed width, and weight of 100 seeds. While soybean mutan line 23.1 higher than Arjasari in yield, seed length, and seed width.
\end{abstract}

Keywords: Soybean · Seed size · Weight of 100 seeds · Variety · Arjasari

Diterima : 26 Juni 2020, Disetujui : 10 Agustus 2020, Dipublikasikan : 12 Agustus 2020 doi: https://doi.org/10.24198/kultivasi.v19i2.25648

\footnotetext{
Yoel, A. · M. Rachmadi

Prodi Agroteknologi, Fakultas Pertanian, Universitas Padjadjaran

Korespondensi: meddy.rachmadi@unpad.ac.id
} 


\section{Pendahuluan}

Kedelai merupakan tanaman pangan semusim yang penting setelah padi dan jagung, dikarenakan memiliki kandungan protein yang tinggi, berkisar antara 40-49\% (Banaszkiewicz, 2012; Sudaryanto dan Swastika, 2007). Kedelai sebagai bahan pangan memiliki kandungan nutrisi yang cukup lengkap dan seimbang karena mengandung kandungan protein, asam lemak tak jenuh, karbohidrat, mineral, vitamin, senyawa phenolik, lechitin, serta kandungan isoflavonoid ( $\mathrm{O}^{\prime}$ Keefe et al., 2015). Hal tersebut menyebabkan kebutuhan kedelai nasional sangat tinggi dan cenderung meningkat setiap tahun.

Produksi kedelai nasional masih relatif rendah dibandingkan dengan kebutuhannya. Rata-rata konsumsi produk berbahan baku kedelai tahun 2012 - 2017 sebesar 2.279.244,7 ton. Sedangkan rata-rata produksi kedelai nasional untuk rentang tahun yang sama sebesar 823.179,11 ton (Pusat dan Sistem Informasi Pertanian, 2013; 2015; 2016; 2018) atau hanya $37,73 \%$ dari kebutuhan nasional. Untuk memenuhi kebutuhan kedelai nasional, pemerintah melakukan impor yang volume dan nilainya cenderung meningkat sejalan dengan meningkatnya jumlah penduduk Indonesia. Pada tahun 2019 Indonesia telah melakukan impor kedelai sebesar 2,67 ton (dengan nilai 1,15 juta US Dollar); atau meningkat 3,2\% dari tahun sebelumnya (Badan Pusat Statistik, 2019).

Rendahnya produksi kedelai nasional disebabkan oleh produktivitas dan luas areal panen yang rendah. Menurut Pusat dan Sistem Informasi Pertanian (2013; 2015; 2016; 2018 ), rata-rata produktivitas kedelai nasional selama lima tahun sampai dengan tahun 2017 sebesar 1,50 ton/ha. Capaian produktivitas tersebut relatif rendah dibandingkan dengan potensi yang dimiliki oleh varietas-varietas unggul kedelai yang telah dilepas. Balai Penelitian Tanaman Aneka Kacang dan Umbi (2016) menyebutkan rata-rata produktivitas kedelai pada kurun waktu 2012 - 2017 sebesar 3,00 ton per hektar. Terlebih lagi apabila dibandingkan dengan capaian produktivitas kedelai di Brazil (3,23 ton/ha), serta Argentina (3,27 ton/ha) (United States Department of Agriculture, 2019).

Relatif rendahnya capaian produktivitas kedelai dipengaruhi oleh tingkat penerapan teknologi budidaya dan kondisi lingkungan agrosistem pertanaman. Indonesia memiliki lingkungan agrosistem pertanaman kedelai yang sangat bervariasi. Sampai saat ini pemerintah telah melepas tidak kurang dari 90 varietas unggul kedelai. Jumlah tersebut masih relatif kecil dibandingkan dengan variasi kondisi lingkungan agrosistem pertanaman kedelai. Menurut Allard (1961), Fehr (1987), dan Acquuah (2012), setiap tanaman memiliki kesesuaian kondisi lingkungan yang berbeda untuk untuk memberikan penampilannya yang maksimal. Oleh karena itu, salah satu upaya peningkatan produksi dapat ditempuh melalui peningkatan perakitan varietas unggul kedelai; yang selanjutnya diuji kesesuaiannya pada kondisi lingkungan tertentu.

Luas areal panen kedelai di Indonesia cenderung semakin menurun. Dalam kurun waktu lima tahun sejak tahun 2012, luas panen kedelai di Indonesia menurun rata-rata 7,16\% setiap tahun (Pusat dan Sistem Informasi Pertanian, 2013; 2015; 2016; 2018, 2019). Luas panen terakhir seluas 355.799 ha. Menurunnya luas areal penanaman tersebut merupakan salah satu indikator berkurangnya minat petani untuk menanam kedelai. Minat tersebut dipengaruhi antara lain oleh keterbatasan varietas unggul berukuran biji besar.

Salah satu harapan petani dan pengguna kedelai adalah ukuran biji yang besar. Harapan tersebut tidak dapat dilepaskan dari pengaruh kedelai impor yang berukuran biji besar. Pemenuhan harapan kedelai berukuran biji besar tidak dapat dihindari. Hasil penelitian yang dilakukan oleh Krisdiana (2015) menunjukkan bahwa sebanyak $97 \%$ responden pengrajin tempe dan $73 \%$ pengrajin tahu di Jawa Tengah memilih biji kedelai berukuran besar sebagai bahan baku pembuatan tahu dan tempe. Hal tersebut menunjukkan perlunya perakitan varietas kedelai dengan ukuran biji besar.

Perakitan varietas kedelai seharusnya juga diarahkan pada daya hasil tinggi dengan ukuran biji besar. Perakitan varietas kedelai berukuran biji besar saat ini belum menjadi sasaran utama dalam pemuliaan kedelai di Indonesia. Hal tersebut sejalan dengan Morrison et al. (2000), Jin et al, (2010), dan Ainsworth et al. (2012), bahwa peningkatan produktivitas kedelai lebih ditunjang oleh faktor jumlah biji per tanaman, tidak oleh faktor ukuran biji yang selama ini relatif tidak berubah. 
Perakitan varietas kedelai berdaya hasil tinggi dengan ukuran biji besar dapat dilakukan melalui induksi mutasi. Menurut Fehr (1987), Broertjes dan van Harten (1988), dan Acquuaah (2012), penggunaan teknik induksi mutasi dapat meningkatkan variasi genetik baru yang sebelumnya tidak ada. Pendekatan induksi mutasi berpotensi untuk kedelai yang memiliki variasi ukuran biji yang sempit. Tidak berbeda dengan pendekatan rekombinasi genetik lainnya, setelah beberapa generasi, mutanmutan kedelai yang terbentuk dilakukan beberapa tahap seleksi sebelum dilepas. Sampai saat ini Kementerian Pertanian telah melepas tidak kurang dari sepuluh varietas unggul kedelai hasil induksi mutasi, diantaranya Mutiara 1 yang potensi produktivitas tinggi (4,10 ton/ ha) dengan ukuran biji besar (bobot biji 23,2 g per seratus butir) yang dilepas tahun 2010 (Balai Penelitian Tanaman Aneka Kacang dan Umbi, 2016). Bobot biji kedelai impor dapat memiliki bobot biji $>30 \mathrm{~g}$ per seratus butir (Susanto et al., 2017; Susanto dan Nugrahaeni, 2016). Tujuan penelitian ini adalah untuk mengevaluasi galur-galur mutan kedelai berdasarkan daya hasil dan ukuran biji.

\section{Bahan dan Metode}

Percobaan ini dilaksanakan di Kebun Percobaan Ciparanje di Jatinangor, Fakultas Pertanian, Universitas Padjadjaran, pada bulan September 2017 sampai Januari 2018. Bahan tanaman yang digunakan terdiri dari galur-galur mutan kedelai generasi ke-lima hasil induksi mutasi Gamma-Ray 250 Gy dari varietas Arjasari (yaitu 1.18, 1.2, 2.17, 8.4, 23.1, 25.10, 25.11, 31.4, 78.16, 79.4, 79.11, 79.12, 79.13, 81.21, 83.39, 85.4, 85.8, 86.9, 87.12) serta varietas Arjasari sebagai varietas cek.

Percobaan menggunakan Rancangan Acak Kelompok (RAK) dengan 20 perlakuan (19 galur mutan kedelai dan satu varietas cek) yang diulang dua kali. Setiap perlakuan ditanam dalam bentuk plot barisan tunggal dengan jarak tanam $300 \mathrm{~cm} \times 50 \mathrm{~cm}$; ditanam dua benih per lubang.

Parameter yang diamati dalam percobaan ini meliputi tinggi tanaman, jumlah buku subur, jumlah cabang per tanaman, panjang cabang per tanaman, jumlah polong per tanaman, jumlah biji per polong, umur panen, panjang biji, lebar biji, tebal biji, bobot 100 biji, dan hasil. Data hasil penelitian dianalisis menggunakan analisis varians dan uji perbedaan rata-rata menggunakan uji Dunnnet, masing-masing pada taraf kepercayaan 95\%, 99\%, dan 99,9\%; menggunakan software $\mathrm{R}$ Studio versi 1.1.463. Hubungan antar karakter agronomi dianalisis menggunakan korelasi Pearson pada taraf nyata $5 \%$.

\section{Hasil dan Pembahasan}

Tingkat kesuburan tanah dari lahan percobaan dikategorikan sedang dengan ordo inceptisol, pH 6,4, kadar C-organik sebesar 1,98\%, N Total 0,17\%, P tersedia 12,14 ppm, dan kadar K sebesar $28,25 \mathrm{mg} / 100 \mathrm{~g}$. Tipe iklim termasuk tipe hujan C3 (Oldeman) yang sesuai untuk pertumbuhan kedelai.

Hasil analisis varians dari data parameter pertumbuhan, hasil dan ukuran biji kedelai terdapat pada Tabel 1, 2, dan 3. Hasil percobaan menunjukkan bahwa terdapat perbedaan tinggi tanaman antar galur-galur kedelai yang diuji dibandingkan dengan cek (varietas Arjasari). Galur 1.2 menunjukkan karakter tinggi tanaman yang lebih pendek dibandingkan dengan varietas Arjasari. Galur-galur 23.1 dan 79.11 juga menunjukkan tinggi tanaman yang lebih pendek dibandingkan dengan cek (Tabel 1). Jumlah buku subur pada galur-galur yang diuji tidak berbeda nyata dengan cek (varietas Arjasari. Hal ini disebabkan pada umumnya mutasi tidak berpengaruh signifikan terhadap peningkatan jumlah buku subur pada tanaman yang dimutasi (Li et al., 2019). Jumlah cabang total dan panjang cabang tidak berbeda nyata antara galur-galur mutan kedelai dengan varietas cek Arjasari (Tabel 1); demikian juga halnya dengan karakter jumlah polong (Tabel 2). Seleksi yang dilakukan pada generasi sebelum $\mathrm{M}_{5}$ pada galur-galur kedelai yang diuji berfokus kepada karakter biji besar dan bobot 100 biji yang tinggi, sehingga seleksi terhadap karakter jumlah polong tidak dilakukan. Oleh karena itu, pada generasi $\mathrm{M}_{5}$ tidak diperoleh galur-galur yang memiliki jumlah polong yang lebih tinggi dari cek.

Jumlah biji per polong menunjukkan hasil yang berbeda tidak signifikan pada berbagai galur yang dibandingkan dengan cek (Tabel 2). Jumlah biji per polong berkorelasi positif dengan karakter jumlah polong per tanaman, 
sehingga jumlah polong per tanaman yang tidak menunjukkan perbedaan yang signifikan terhadap cek akan memiliki korelasi positif terhadap parameter jumlah biji per polong yang memiliki hasil uji yang berbeda tidak signifikan terhadap cek (Painkra et al., 2018; Vu et al., 2019).

Tabel 1. Rata-rata komponen pertumbuhan galurgalur mutan kedelai di Ciparanje, Sumedang, Jawa Barat

\begin{tabular}{|c|c|c|c|c|}
\hline Galur & $\begin{array}{c}\text { Tinggi } \\
\text { Tanaman } \\
(\mathrm{cm})\end{array}$ & $\begin{array}{l}\text { Buku } \\
\text { Subur }\end{array}$ & $\begin{array}{l}\text { Jumlah } \\
\text { Cabang }\end{array}$ & $\begin{array}{c}\text { Panjang } \\
\text { Cabang } \\
(\mathrm{cm})\end{array}$ \\
\hline $\mathrm{A}(\mathrm{Cek})$ & 83 & 13 & 6 & 190 \\
\hline B & 99 & 13 & 3 & 100 \\
\hline C & $62^{*}$ & 10 & 4 & $48^{* *}$ \\
\hline $\mathrm{D}$ & 69 & 11 & 3 & $68^{*}$ \\
\hline E & 69 & 11 & 7 & 116 \\
\hline $\mathrm{F}$ & $59^{* *}$ & 12 & 4 & 102 \\
\hline G & 96 & 9 & 2 & $56^{* *}$ \\
\hline $\mathrm{H}$ & 93 & 13 & 4 & $84^{*}$ \\
\hline I & 96 & 9 & 2 & $56^{* *}$ \\
\hline $\mathrm{J}$ & 75 & 11 & 4 & 114 \\
\hline K & 92 & 14 & 5 & 151 \\
\hline L & $50^{* * *}$ & 8 & 3 & $23^{* *}$ \\
\hline M & 83 & 11 & 5 & 115 \\
\hline $\mathrm{N}$ & 77 & 12 & 5 & $75^{*}$ \\
\hline $\mathrm{O}$ & 89 & 14 & 4 & 151 \\
\hline $\mathrm{P}$ & 76 & 12 & 6 & 145 \\
\hline Q & 79 & 12 & 8 & $85^{*}$ \\
\hline $\mathrm{R}$ & 82 & 12 & 4 & 106 \\
\hline S & 83 & 11 & 6 & 97 \\
\hline $\mathrm{T}$ & 91 & 11 & 3 & $77^{*}$ \\
\hline
\end{tabular}

Keterangan: ${ }^{*}=$ Berbeda nyata terhadap cek pada uji Dunnet taraf $5 \%\left({ }^{*}\right) ; 1 \%\left({ }^{* *}\right) ; 0,1 \%\left({ }^{* * *}\right) . \mathrm{A}=$ Arjasari; B $=1.18 ; \mathrm{C}=1.2 ; \mathrm{D}=2.17 ; \mathrm{E}=8.4 ; \mathrm{F}=23.1 ; \mathrm{G}=25.10 ;$ $\mathrm{H}=25.11 ; \mathrm{I}=31.4 ; \mathrm{J}=78.16, \mathrm{~K}=79.4 ; \mathrm{L}=79.11 ; \mathrm{M}=79.12 ;$ $\mathrm{N}=79.13 ; \mathrm{O}=81.21 ; \mathrm{P}=83.39 ; \mathrm{Q}=85.4 ; \mathrm{R}=85.8 ; \mathrm{S}=$ $86.9 ; \mathrm{T}=87.12$
Umur Panen menunjukkan hasil yang tidak berbeda nyata pada galur-galur kedelai yang diuji dibandingkan dengan cek. Umur panen berkisar antara 105 sampai dengan 109 hari (Tabel 2). Galur 25.10, 25.11, 31.4, 78.16, dan 87.12 menunjukkan umur panen paling lama yaitu 109 hari. Galur 79.11 menunjukkan umur panen lebih genjah, yaitu 106 hari, sedangkan galur 1.18, 1.2, 2.17, 23.1, 78.16, 79.4, 79.12, 79.13, 81.21, 83.39, 85.4, 85.8, dan 86.9 memiliki umur panen setara dengan cek yaitu 105 hari. Penelitian yang dilakukan oleh Petter et al. (2014) menunjukkan tidak terdapatnya korelasi antara umur panen terhadap berbagai parameter pertumbuhan dan daya hasil seperti tinggi tanaman, bobot 100 biji, dan daya hasil.

Komponen ukuran biji berupa panjang biji, lebar biji, tebal biji, dan bobot 100 butir dapat dilihat pada Tabel 4. Hasil uji Dunnet menunjukkan galur-galur mutan kedelai 1.18, 1.2, 23.1, 25.10, 25.11, 31.4, 79.4, 79.11, 79.12, 79.13, 81.21, 83.39, 85.4, 85.8, dan 86.9 dan memiliki nilai panjang biji lebih besar dibandingkan dengan cek.

Hasil uji Dunnet terhadap variabel lebar biji juga menunjukkan beberapa galur mutan kedelai memiliki nilai yang lebih besar dibandingkan cek (varietas Arjasari); galur-galur tersebut adalah 1.18, 1.2, 23.1, 25.11, 31.4, 79.11, 79.4, 85.4, 83.39, dan 87.12. Demikian juga dengan hasil uji Dunnet untuk tebal biji yang menunjukkan nilai yang lebih tinggi untuk galur-galur mutan yang diuji dibandingkan dengan cek (varietas Arjasari), yaitu galur 1.18, 1.2, 23.1, 25.10, 25.11, 31.4, 79.4, 79.11, 83.39, 85.4, dan 87.12 .

Tabel 2. Korelasi pearson antar karakter agronomi tanaman kedelai.

\begin{tabular}{|c|c|c|c|c|c|c|c|c|c|c|c|c|c|}
\hline & PB & LB & TB & B100 & JBT & JPT & JBP & UP & TT & JBT & JBST & $\mathrm{JCT}$ & PCT \\
\hline PB & 1 & & & & & & & & & & & & \\
\hline LB & $0,57^{*}$ & 1 & & & & & & & & & & & \\
\hline $\mathrm{TB}$ & $0,38^{*}$ & $0,59 *$ & 1 & & & & & & & & & & \\
\hline B100 & 0,5 & $0,45^{*}$ & $0,35^{*}$ & 1 & & & & & & & & & \\
\hline JBT & $-0,17$ & 0,01 & $-0,18$ & $-0,35^{*}$ & 1 & & & & & & & & \\
\hline JPT & $-0,11$ & 0,07 & $-0,15$ & $-0,29$ & 0,76 & 1 & & & & & & & \\
\hline JBP & $-0,09$ & $-0,24$ & $-0,05$ & $-0,14$ & 0,18 & $-0,05^{*}$ & 1 & & & & & & \\
\hline UP & $0,48^{*}$ & 0,01 & 0,18 & 0,14 & $-0,18$ & $-0,19$ & 0,29 & 1 & & & & & \\
\hline $\mathrm{TT}$ & 0,13 & 0,08 & $-0,02$ & $-0,12$ & 0,27 & 0,28 & $-0,01$ & $0,44^{*}$ & 1 & & & & \\
\hline JBT & $-0,12$ & $-0,01$ & $-0,08$ & $-0,29$ & $0,43^{*}$ & $0,48^{*}$ & $-0,27$ & $-0,21$ & $0,38^{*}$ & 1 & & & \\
\hline JBST & $-0,21$ & $-0,1$ & $-0,23$ & $-0,28$ & $0,49^{*}$ & $0,58^{*}$ & $-0,32^{*}$ & $-0,25$ & $0,35^{*}$ & 0,9 & 1 & & \\
\hline JCT & $-0,21$ & $-0,05$ & $-0,27$ & $-0,12$ & 0,19 & 0,22 & $-0,29$ & $-0,46^{*}$ & $-0,01$ & $0,32^{*}$ & $0,46^{*}$ & 1 & \\
\hline PCT & $-0,27$ & $-0,14$ & $-0,42^{*}$ & $-0,25$ & $0,46^{*}$ & $0,48^{*}$ & $-0,22$ & $-0,37^{*}$ & 0,3 & 0,64 & 0,7 & $0,58^{*}$ & 1 \\
\hline
\end{tabular}

Keterangan : $\left({ }^{*}\right)=$ berbeda nyata pada taraf signifikansi 5\%; PB= Panjang Biji; LB= Lebar Biji; TB= Tebal Biji; B100= Bobot 100 biji; JBT= Jumlah Biji/Tanaman JPT= Jumlah Polong/Tanaman UP=Umur Panen; TT =Tinggi Tanaman; JBT: Jumlah Buku/Tanaman; JBST: Jumlah Buku Subur/Tanaman; JCT= Jumlah Cabang/Tanaman; PCT= Panjang Cabang/Tanaman; 
Tabel 3. Rata-rata jumlah polong, jumlah biji per polong, umur panen, dan hasil galur-galur mutan kedelai di Ciparanje, Sumedang, Jawa Barat,

\begin{tabular}{|c|c|c|c|c|}
\hline Galur & $\begin{array}{l}\text { Jumlah } \\
\text { Polong }\end{array}$ & $\begin{array}{c}\text { Jumlah } \\
\text { Biji/ } \\
\text { Polong }\end{array}$ & $\begin{array}{l}\text { Umur } \\
\text { Panen } \\
\text { (hari) }\end{array}$ & $\begin{array}{c}\text { Daya } \\
\text { Hasil } \\
\text { (kg/Plot) }\end{array}$ \\
\hline $\mathrm{A}(\mathrm{Cek})$ & 44 & 3 & 105 & 2,15 \\
\hline B & 58 & 3 & 105 & 2,48 \\
\hline $\mathrm{C}$ & 49 & 3 & 105 & 2,14 \\
\hline $\mathrm{D}$ & 34 & 3 & 105 & 1,70 \\
\hline $\mathrm{E}$ & 41 & 3 & 105 & 1,21 \\
\hline $\mathrm{F}$ & 79 & 3 & 105 & $4,43^{* *}$ \\
\hline G & 47 & 3 & 109 & 2,24 \\
\hline $\mathrm{H}$ & 49 & 3 & 109 & 2,62 \\
\hline I & 40 & 3 & 109 & 2,18 \\
\hline J & 53 & 3 & 105 & 2,88 \\
\hline K & 73 & 3 & 105 & 3,60 \\
\hline $\mathrm{L}$ & 20 & 2 & 106 & 0,78 \\
\hline M & 61 & 3 & 105 & 2,55 \\
\hline $\mathrm{N}$ & 57 & 3 & 105 & 2,67 \\
\hline $\mathrm{O}$ & 85 & 3 & 105 & 4,26 \\
\hline $\mathrm{P}$ & 74 & 3 & 105 & 3,70 \\
\hline Q & 51 & 3 & 105 & $3,21^{* *}$ \\
\hline $\mathrm{R}$ & 60 & 3 & 105 & 3,65 \\
\hline$S$ & 46 & 2 & 105 & 2,92 \\
\hline $\mathrm{T}$ & 53 & 3 & 109 & 2,66 \\
\hline \multicolumn{5}{|c|}{$\begin{array}{l}\text { Keterangan: }{ }^{*}=\text { Berbeda nyata terhadap cek pada uji Dunnet } \\
\left.\text { pada taraf nyata } 5 \%\left({ }^{*}\right) ; 1 \%\left({ }^{* *}\right) ; 0,1 \%{ }^{* * *}\right) . \mathrm{A}=\text { Arjasari; } \mathrm{B}= \\
\text { 1.18; } \mathrm{C}=1.2 ; \mathrm{D}=2.17 ; \mathrm{E}=8.4 ; \mathrm{F}=23.1 ; \mathrm{G}=25.10 ; \mathrm{H}=25.11 ; \mathrm{I}=31.4 ; \\
\mathrm{J}=78.16, \mathrm{~K}=79.4 ; \mathrm{L}=79.11 ; \mathrm{M}=79.12 ; \mathrm{N}=79.13 ; \mathrm{O}=81.21 ; \mathrm{P}= \\
83.39 ; \mathrm{Q}=85.4 ; \mathrm{R}=85.8 ; \mathrm{S}=86.9 ; \mathrm{T}=87.12\end{array}$} \\
\hline
\end{tabular}

Tabel 4. Rata-rata panjang biji, tebal biji, lebar biji, dan bobot 100 biji (g) galur-galur mutan kedelai di Ciparanje, Sumedang, Jawa Barat.

\begin{tabular}{|c|c|c|c|c|}
\hline Galur & $\begin{array}{l}\text { Panjang } \\
\text { Biji (cm) }\end{array}$ & $\begin{array}{c}\text { Lebar } \\
\text { Biji } \\
(\mathrm{cm})\end{array}$ & $\begin{array}{c}\text { Tebal } \\
\text { Biji } \\
(\mathrm{cm})\end{array}$ & $\begin{array}{c}\text { Bobot } 100 \\
\text { Biji }(g)\end{array}$ \\
\hline $\mathrm{A}(\mathrm{Cek})$ & 7,86 & 6,37 & 4,96 & 19,81 \\
\hline B & $8,97^{* * *}$ & $7,13^{* *}$ & $5,75^{*}$ & 21,03 \\
\hline C & $9,41^{* * *}$ & 6,80 & 5,45 & 20,72 \\
\hline D & $8,80^{* * *}$ & $6,85^{*}$ & 5,46 & $24,18^{* * *}$ \\
\hline $\mathrm{E}$ & $9,13^{* * *}$ & $6,96^{*}$ & $5,61^{*}$ & $22,78^{* * *}$ \\
\hline $\mathrm{F}$ & $8,90 * * *$ & $7,04^{* *}$ & 5,46 & $21,45^{*}$ \\
\hline G & $9,74^{* * *}$ & $6,87^{*}$ & 5,54 & $21,87^{*}$ \\
\hline $\mathrm{H}$ & $9,48^{* * *}$ & 6,75 & 5,30 & 20,40 \\
\hline $\mathrm{I}$ & $9,30 * * *$ & 6,71 & 5,60 * & $22,39 * *$ \\
\hline $\mathrm{J}$ & $9,06^{* * *}$ & $6,85^{*}$ & 5,20 & $21,54^{*}$ \\
\hline K & $9,78^{* * *}$ & $7,11^{\text {** }}$ & 5,39 & $21,82^{*}$ \\
\hline $\mathrm{L}$ & $9,09 * * *$ & $6,92^{*}$ & $5,74^{*}$ & $21,83^{*}$ \\
\hline M & $8,81^{* * *}$ & 6,82 & 5,41 & 19,59 \\
\hline $\mathrm{N}$ & 7,79 & 6,42 & 5,17 & 19,38 \\
\hline $\mathrm{O}$ & 8,12 & 6,62 & 5,49 & 20,65 \\
\hline $\mathrm{P}$ & $8,77^{* * *}$ & 6,77 & 5,40 & 20,55 \\
\hline Q & $8,85^{* * *}$ & 6,70 & 5,46 & $21,48^{*}$ \\
\hline $\mathrm{R}$ & $8,46^{*}$ & 6,83 & 5,33 & 20,92 \\
\hline$S$ & 8,35 & $6,95^{*}$ & 5,40 & 20,62 \\
\hline $\mathrm{T}$ & $9,17^{* * *}$ & $6,94^{*}$ & $5,58^{*}$ & 21,42 \\
\hline \multicolumn{5}{|c|}{$\begin{array}{l}\text { Keterangan: }{ }^{*}=\text { Berbeda nyata terhadap cek pada uji Dunnet } \\
\left.\text { pada taraf nyata } 5 \%\left({ }^{*}\right) ; 1 \%\left({ }^{* *}\right) ; 0,1 \%{ }^{* * *}\right) . \mathrm{A}=\text { Arjasari; } \mathrm{B}= \\
1.18 ; \mathrm{C}=1.2 ; \mathrm{D}=2.17 ; \mathrm{E}=8.4 ; \mathrm{F}=23.1 ; \mathrm{G}=25.10 ; \mathrm{H}=25.11 ; \mathrm{I}=31.4 ; \\
\mathrm{J}=78.16, \mathrm{~K}=79.4 ; \mathrm{L}=79.11 ; \mathrm{M}=79.12 ; \mathrm{N}=79.13 ; \mathrm{O}=81.21 ; \mathrm{P}= \\
83.39 ; \mathrm{Q}=85.4 ; \mathrm{R}=85.8 ; \mathrm{S}=86.9 ; \mathrm{T}=87.12\end{array}$} \\
\hline
\end{tabular}

Daya hasil diperoleh dari data per rumpun yang dengan asumsi jarak tanam $25 \times 25 \mathrm{~cm}$. variabel daya hasil menunjukkan galur 23.1 dan 85.4 menunjukkan hasil yang lebih tinggi dibandingkan dengan cek (varietas Arjasari). Hal ini sesuai dengan hasil yang ditunjukkan oleh data pendukung berupa komponen pertumbuhan dan hasil (Tabel 3).

\section{Kesimpulan}

Hasil penelitian menunjukkan bahwa terdapat galur-galur mutan kedelai yang memiliki daya hasil dan ukuran biji yang lebih tinggi dari varietas Arjasari. Galur mutan kedelai 85.4 lebih tinggi dibandingkan Arjasari pada daya hasil, panjang biji, lebar biji, dan bobot 100 biji. Sedangkan galur mutan kedelai 23.1 lebih tinggi dibandingkan Arjasari pada daya hasil, panjang biji, dan lebar biji.

\section{Daftar Pustaka}

Acquaah, G. 2012. Principles of Plant Genetics and Breeding. Blackwell publishing. USA.

Ainsworth, E.A., C.R. Yendrek, J.A. Skoneczka, S.P. Long .2012. Accelerating yield potential in soybean: potential targets for biotechnological improvement. Plant Cell Environ 35(1):38-52.

Allard, R.W. 1961. Principles of Plant Bredding. John Wiley \& Sons, Inc. New York, Chicester, Brisbane, Toronto, Singapore.

Badan Pusat Statistik. 2019. Impor Kedelai Menurut Negara Asal Utama. Badan Pusat Statistik.

Balai Penelitian Tanaman Aneka Kacang dan Umbi. 2016. Deskripsi Varietas Unggul Aneka Kacang dan Umbi. Balai Penelitian Tanaman Aneka Kacang dan Umbi. Badan Penelitian dan Pengembangan Pertanian, Kementerian Pertanian.

Banaszkiewicz, T. 2012. Nutritional Value of Soybean Meal. Soybean and Nutrition.

Broertjes, C. and A.M. van Harten. 1988. Applied Mutation Breeding for Vegetativekly Propagated Crops. Elsevier Science Publishing Company Inc. New York.

Fehr, W.R. 1987. Principles of cultivar development, volume I: Theory and 
Tehcnique. MacMillan Publishing. New York.

Jin, J., X. Liu, G. Wang, L. Mi, Z. Shen, X. Chen, S.J. Herbert. 2010. Agronomic and physiological contributions to the yield improvement of soybean cultivars released from 1950 to 2006 in Northeast China. Field Crops Res 115:116-123.

Krisdiana, R. 2015. "Preferensi Industri Tahu dan Tempe terhadap Ukuran dan Warna Biji Kedelai. Iptek Tanaman Pangan. 2(1): 123-130.

Li M.W., Z. Wang, J. Bingjun, K. Akito, W. FukLing, Z. Guohong, H. Tianfu, C. Gyuhwa, N. Henry, L. Hon-Ming. 2019. Impacts of genomic research on soybean improvement in East Asia. Theoretical and applied genetics (TAG). 133(5): 1655-1678.

Morrison, M.J., H.D. Voldeng, E.R. Cober. 2000. Agronomic changes from 58 years of genetic improvement of short-season soybean cultivars in Canada. Agron J 92:780-784.

O'Keefe, S., L. Bianchi, dan J. Sharman. 2015. Soybean nutrition. SM Journal of Nutrition and Metabolism, 1(2): 1006.

Petter, F.A., A.N. de Francisco , S.B. Willian, A.A. Fernandes, P.P. Leandro, B.L. Larissa, A.G. Geraldo. 2014. Phenotypic correlations and path analysis of soybean production components in the brazilian cerrado of Piauí state. Revista de Ciências Agrarias Amazon Journal of Agricultural and Environmental Sciences (AJAES). 57(3): 273-279

Painkra, P., R. Shrivatava, S.K. Nag, I. Kute. 2018. Correlation analysis for seed yield and its attributing traits in soybean (Glycine $\max$ L. Merrill). International Journal of Current Microbiology and Applied Sciences (IJCMAS). 7(04): 2034-2040.
Pusat dan Sistem Informasi Pertanian. 2013. Outlook Komoditas Pertanian Tanaman Pangan : Kedelai. Pusat dan Sistem Informasi Pertanian. Kementerian Pertanian.

Pusat dan Sistem Informasi Pertanian. 2015. Outlook Komoditas Pertanian Tanaman Pangan : Kedelai. Pusat dan Sistem Informasi Pertanian. Kementerian Pertanian.

Pusat dan Sistem Informasi Pertanian. 2016. Outlook Komoditas Pertanian Tanaman Pangan : Kedelai. Pusat dan Sistem Informasi Pertanian. Kementerian Pertanian.

Pusat dan Sistem Informasi Pertanian. 2018. Outlook Komoditas Pertanian Tanaman Pangan : Kedelai. Pusat dan Sistem Informasi Pertanian. Kementerian Pertanian.

Sudaryanto, T. dan D.K.S. Swastika. 2007. Ekonomi Kedelai di Indonesia: Kedelai Teknik Produksi dan Pengembangan. (Bps): 1-27.

Susanto, A. N., R. Suhendi, Marwoto, Subandi, J.R. Hidajat. 2017. Pedoman Umum Produksi dan Distribusi Benih Sumber Kedelai. Pusat Penelitian dan Pengembangan Tanaman Pangan. Bogor.

Susanto, G. W. A. dan N. Nugrahaeni. 2016. Pengenalan dan karakteristik varietas unggul kedelai. Prosiding Seminar Hasil Penelitian Tanaman Aneka Kacang dan Umbi 2011. (61): 17-28.

United States Department of Agriculture. 2019 World Agricultural Production, Circular Series May 2019. USDA. USA

Vu T.T.H., T.C.T. Thi, H.V. Dinh, T.N. Thanh, N.P. Thi. 2019. Correlations and path coefficients for yield related traits in soybean progenies. Asian Journal of Crop Science. 11(2): 32-39 